\title{
ANALISIS FAKTOR-FAKTOR YANG MEMPENGARUHI PREFERENSI KONSUMEN TERHADAP HOTEL SYARIAH
}

\section{ANALYSIS OF FACTORS AFFECTING CONSUMER PREFERENCES OF THE HOTEL SYARIAH}

\author{
N. Rahardi1a dan R. Wiliasih ${ }^{2}$
}

\begin{abstract}
1aProgram Studi Ekonomi Syariah Departemen Ilmu Ekonomi Institut Pertanian Bogor, Kampus IPB Darmaga Bogor, Jalan Raya Darmaga, Bogor, Jawa Barat 16680.

2Program Studi Ekonomi Syariah Departemen Ilmu Ekonomi Institut Pertanian Bogor, Kampus IPB Darmaga Bogor, Jalan Raya Darmaga, Bogor, Jawa Barat 16680.
\end{abstract}

\begin{abstract}
The research aimed to look at the factors that influence consumer preference towards sharia hotel. Sampling using purposive sampling with data analysis using logistic regression and descriptive analysis. The results of data analysis showed that the factors that influence consumer preference towards hotel sharia is the knowledge, the image of the hotel, the customer service, locations, processes, facilities, andreligiosity.
\end{abstract}

Keywords: hotel sharia, tourism, preferences, logistic regression.

\begin{abstract}
ABSTRAK
Tujuan penelitian untuk melihat faktor-faktor yang mempengaruhi preferensi konsumen terhadap hotel syariah. Pengambilan sampel menggunakan teknik Purposive Sampling dengan analisis data menggunakan metode regresi logistik dan analisis deskriptif. Hasil analisis data menunjukkan bahwa faktor-faktor yang mempengaruhi preferensi konsumen terhadap hotel syariah adalah pengetahuan, citra hotel, layanan pelanggan, lokasi, proses, fasilitas, dan religiusitas.
\end{abstract}

Kata kunci: hotel syariah, pariwisata, preferensi, regresi logistik. 
Rahardi, Naufal. 2016. Analisis Faktor-faktor yang Mempengaruhi Preferensi Konsumen terhadap Hotel Syariah, Jurnal Syarikah 2 (1): 180-192

\section{PENDAHULUAN}

Keanekaragaman budaya dan keindahan alam nusantara menjadikan Indonesia sebagai salah satu tujuan wisata masyarakat dari berbagai penjuru dunia. Banyaknya wisatawan mancanegara yang berkunjung ke Indonesia mencapai 9.435.411 pengunjung pada tahun 2014 (BPS 2015). Jumlah wisatawan tersebut meningkatkan laju pertumbuhan kumulatif Produk Domestik Bruto (PDB) menurut lapangan usaha pada bidang hotel rata-rata sebesar 9,83\% pada tahun 2012 (BPS 2015). Berdasarkan jumlah wisatawan dan persentase laju pertumbuhan PDB menurut lapangan usaha pada bidang hotel tersebut, merupakan peluang besar untuk meningkatkan populasi hotel di Indonesia. Peningkatan jumlah wisatawan mancanegara yang berkunjung ke Indonesia dari tahun 2010 sampai tahun 2014 berpengaruh terhadap tingkat hunian (occupancy rate) pada hotel berbintang sebesar 52,56\% pada tahun 2014 (BPS 2015).Peningkatan jumlah wisatawan nusantara mampu menghasilkan devisa negara sebesar 213,94 Triliun rupiah pada tahun 2014 (BPS 2015).

Indonesia merupakan negara dengan penduduk mayoritas muslim terbesar di dunia, dengan jumlah penduduk beragama Islam sebanyak 209 juta jiwa. Sebagai negara dengan mayoritas penduduk beragama Islam, fasilitas, dan infrastuktur pariwisata yang ada Indonesia telah dianggap cukup ramah pada para wisatawan muslim (Kemenparekraf, 2013). Menurut BPS (2013) wisatawan mancanegara tahun 2010, dari total 7 juta wisatawan mancanegara yang berkunjung ke Indonesia sebanyak 1,2 juta wisatawan atau sekitar 18\% merupakan wisatawan muslim yang berpotensi dalam mengembangkan wisata syariah. Meningkatnya kegiatan wisata ini, terkait dengan perintah Allah SWT yang tertulis dalam Al-Quran Surat Al-Ankabut ayat 20 "Katakanlah, berjalanlah di bumi, maka perhatikanlah bagaimana (Allah) memulai penciptaan (makhluk), kemudian Allah menjadikan keadaan yang akhir. Sungguh, Allah Mahakuasa atas segala sesuatu" (29:20).

Hotel syariah menjadi sebuah pilihan hunian yang bersifat sementara bagi masyarakat muslim Indonesia dan mancanegara. Adanya hotel syariah di Indonesia diharapkan dapat mengambil pangsa pasar pariwisata dari Timur Tengah. Pembelanjaan dari sektor pariwisata Uni Emirate Arab yang mencapai US\$1.700 per orang (Good News, 2015) dapat meningkatkan pertumbuhan hotel syariah di Indonesia. Hotel syariah memiliki beberapa pelayanan fasilitas hotel seperti petunjuk arah shalat, menyediakan makanan dan minuman halal saja, mushola hotel, Al-Quran, dan peralatan shalat lengkap pada setiap kamar hotel. Dalam penerimaan pengunjung, pihak hotel syariah memiliki SOP (Standar Operasi Produk) yang tertulis, sehingga menerima pengunjung lawan jenis harus memiliki status keluarga atau hubungan suami istri. Pekerja perempuan diwajibkan berkerudung dan untuk pria berpakaian sopan. Hotel yang menerapkan prinsip syariah sendiri merupakan inovasi baru bagi perindustrian hotel karena dapat mengambil pangsa pasar baru yang lebih kompetitif. 
Menurut Peraturan Menteri Pariwisata dan Ekonomi Kreatif Republik Indonesia Nomor 2 Tahun 2014 usaha hotel syariah digolongkan menjadi dua yaitu Hotel Syariah Hilal-1 dan Hotel Syariah Hilal-2 yang digunakan sebagai dasar adanya penerapan hotel syariah. Hotel Syariah Hilal-1 merupakan penggolongan untuk usaha hotel syariah yang dinilai memenuhi seluruh kriteria usaha hotel syariah yang diperlukan untuk melayani kebutuhan minimal wisatawan muslim. Hotel Syariah Hilal-2 adalah penggolongan untuk usaha hotel syariah yang dinilai memenuhi seluruh kriteria usaha hotel syariah yang diperlukan untuk melayani kebutuhan moderat wisatawan muslim.

Hotel Sofyan merupakan salah satu hotel syariah yang mendapatkan penghargaan sebagai World Halal Travel Award 2015 yang diselenggarakan di Dubai. Namun, pada prakteknya jumlah pengunjung yang menginap di Hotel Sofyan Inn Srigunting Bogor mengalami penurunan selama tahun 2015 dibandingkan dengan jumlah pengunjung pada tahun 2014.

Rata-rata jumlah pengunjung Hotel Sofyan Inn Srigunting pada tahun 2015 perbulan hanya berjumlah 374 pengunjung, sedangkan untuk pertahunnya sejumlah 4.488 pengunjung. Penurunan jumlah pengunjung yang terjadi selama tahun 2015 tidak berbanding lurus dengan prestasi Hotel Sofyan Inn Srigunting sebagai pemenang World Halal Travel Award 2015. Berdasarkan latar belakang tersebut, maka tujuan dari penelitian ini adalah menganalisis faktor-faktor yang mempengaruhi preferensi konsumen terhadap hotel syariah pada Hotel Sofyan Inn Srigunting Bogor.

\section{MATERI DAN METODE}

Kartini (2014) meneliti tentang variabel yang mempengaruhi keputusan pemilihan hotel syariah dengan metode regresi linier berganda. Persepsi pelanggan dari fisik dan iklan kuat signifikan mempengaruhi keputusan pelanggan dalam memilih layanan hotel Syariah. Lokasi dan pelayanan memiliki pengaruh yang signifikan lemah pada pengambilan keputusan. Hasil uji variabel, persepsi tamu hotel terhadap produk, tarif dan proses tidak berpengaruh terhadap keputusan tamu hotel menginap. Variabel iklan, lokasi, pelayanan dan sarana fisik berpengaruh terhadap keputusan tamu hotel menginap.

Susanti (2004) melakukan penelitian mengenai analisis tingkat kepuasan konsumen terhadap kualitas pelayanan (studi kasus: Hotel Sofyan Betawi, Menteng Jakarta) dengan menggunakan metode (IPA) Importance Performance Analysis. Hasil dari penelitian adalah pada kuadran B, atribut-atribut yang ada perlu dipertahankan prestasinya karena pada umumnya tingkat kinerja pihak hotel telah sesuai dengan tingkat kepentingan atau harapan konsumen yakni kesigapan karyawan hotel dalam melayani konsumen, kesigapan karyawan hotel dalam menangani keluhan konsumen, keamanan dan kenyamanan hotel, kejujuran karyawan hotel, pelayanan yang sopan dan ramah, image/citra hotel dimata konsumen, kepekaan karyawan hotel terhadap keinginan dan kebutuhan tamu, dan pemberian pelayanan terhadap semua konsumen tanpa pilih-pilih.

Hotel syariah adalah hotel yang menyediakan jasa pelayanan penginapan, makan, dan minum, serta jasa lainnya bagi umum, dikelola secara komersial serta 
memenuhi ketentuan persyaratan yang ditetapkan pemerintah, industri, dan syariah (Sofyan Hotel 2015). Menurut Sabri (2010) ketentuan-ketentuan syariah yang berupa larangan yang harus dijauhi dalam hukum mu'amalah, termasuk didalamnya usaha perhotelan adalah adanya sesuatu yang melanggar syariah, membahayakan, penipuan, dan bersifat meragukan.

Rezeki dan Reza (2011) menyimpulkan bahwa, berdasarkan nilai-nilai tersebut diatas, lalu dilakukan pendalaman terhadap operasional hotel dan dibuatlah standar atau kriteria hotel syariah sebagai berikut:

1. Fasilitas yang dapat memberi manfaat bagi tamu. Fasilitas-fasilitas yang mengakibatkan kerusakan, kemungkaran, perpecahan, membangkitkan hawa nafsu, eksploitasi wanita, dan lain yang sejenis ditiadakan. Penggunaan fasilitas yang disediakan juga disesuaikan dengan tujuan diadakannya sehingga tidak terjadi penyalahgunaan fasilitas.

2. Tamu yang check in khususnya bagi pasangan lawan jenis dilakukan seleksi tamu (reception policy). Seleksi dilakukan untuk mengetahui apakah pasangan merupakan suami istri atau keluarga. Seleksi tersebut didasarkan pada dua hal yaitu gelagat (pasangan tersebut lebih canggung atau terlihat mesra, mengucapkan kata-kata sayang pada pasangannya, berjauhan pada saat mendatangi counter front office) dan penampilan (pasangan wanita berpenampilan seksi, pasangan wanita mengenakan seragam sekolah dan masih belia, tidak membawa perlengkapan menginap (koper) serta perbedaan usia cukup mencolok.

3. Pemasaran terbuka bagi siapa saja baik pribadi maupun kelompok, formal maupun informal, dengan berbagai macam suku, agama, ras dan golongan. Asalkan aktifitas tamu tersebut tidak dilarang oleh negara dan tidak merupakan penganjur kerusakan, kemungkaran, permusuhan dan lain sejenisnya.

4. Makanan dan minuman yang disediakan adalah makanan dan minuman yang dijamin kehalalannya baik bahan-bahan maupun proses pembuatannya, serta baik bagi kesehatan tubuh yang memakannya.

5. Dekorasi dan ornamen yang disesuaikan dengan nilai-nilai keindahan dalam Islam serta tidak bertentangan dengan syariah. Ornamen patung ditiadakan dan lukisan mahluk hidup dihindari. Dekorasi tidak harus dalam bentuk kaligrafi.

6. Operasional:

a. Kebijakan: meliputi kebijakan manajemen, peraturan-peraturan yang dibuat, kerjasama dengan pihak luar, investasi dan pengembangan usaha dilakukan sesuai dengan prinsip syariah Islam.

b. Pengelolaan SDM: meliputi penerimaan dan perekrutan SDM, tidak membedakan suku, agama, ras dan golongan selama memenuhi standar kualifikasi yang telah ditentukan. Perusahaan harus jujur kepada karyawan dan memberikan pelatihan-pelatihan yang dibutuhkan karyawan.

c. Pengelolaan SDM mengacu pada peningkatan kualitas yang mengacu pada peningkatan kualitas yang mencakup tiga hal, etika, pengetahuan dan keahlian.

d. Keuangan yaitu pengelolaan keuangan menggunakan akuntansi syariah dan menggunakan bank dan 
asuransi syariah sebagai mitra. Jika perusahaan mempunyai keuntungan yang mencukupi nilai wajib zakat maka perusahaan berkewajiban mengeluarkan zakat.

7. Adanya sebuah lembaga yakni Dewan Pengawas Syariah (DPS) yang bertugas mengawasi jalannya operasional hotel secara syariah dan yang akan memberikan arahan dan menjawab masalah yang muncul dilapangan. Lembaga ini diambil dan disetujui oleh Dewan Syariah Nasional (DSN) yang menujuk anggotanya untuk menjadi Dewan Pengawas Syariah.

Pelayanan yang diberikan adalah pelayanan yang sesuai kaidah Islam yang memenuhi aspek keramah-tamahan, bersahabat, jujur, amanah, suka membantu dan mengucapkan kata maaf dan terimakasih.Pelayanan yang dilakukan juga harus pada batas-batas yang dibolehkan oleh syariat Islam, misalnya tidak menjurus kepada khalwat.

Dalam ekonomi Islam konsep maslahat atau kesejahteraan sosial atau utilitas untuk kebaikan bersama merupakan tujuan yang ingin dicapai antara individu dengan masyarakat, baik dalam urusan ekonomi maupun urusan lainnya. Seperti hal nya dapat dikelompokkan semua masalah baik yang berupa masalih (utilitas, manfaat) maupun mafasid (disutilitas, kerusakan) dalam meningkatkan kesejahteraan sosial (Karim 2007). Dalam pandangan Islam keinginan manusia akan harta tidak akan pernah terpuaskan. Tidak hanya menyadari keinginan manusia untuk mengumpulkan kekayaan, ditakutkan menjurus kepada keserakahan dan pengejaran nafsu pribadi. Hal ini merupakan cara pandang yang sedang dibentuk oleh hotel syariah yang memberikan pandangan tidak hanya semata-mata mencari keuntungan, tetapi berpandangan untuk meningkatkan maslahah bagi seluruh masyarakat.

Pada teori ekonomi Islam dapat digambarkan secara grafis tingkat utilitas yang lebih tinggi digambarkan dengan utility function yang terletak disebelah kanan atas (Gambar 1). Dapat diartikan semakin tinggi indifference curve berarti semakin banyak barang yang dapat dikonsumsi yang menunjukkan semakin tinggi tingkat kepuasan konsumen.

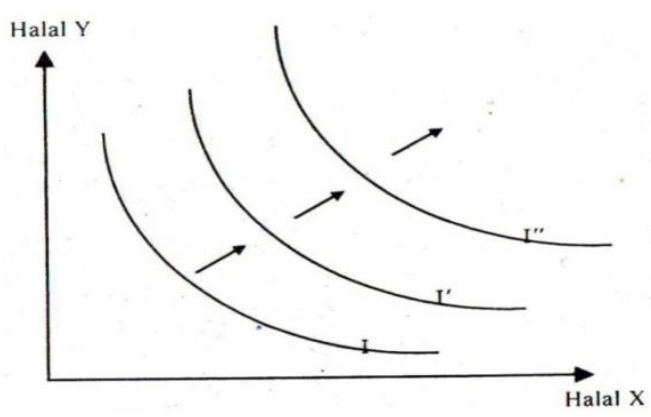

Gambar 1. Utility function

Untuk konsumen, jika kurva semakin bergerak ke kanan atas utility function berarti mengindikasikan bahwa semakin baik. Dalam pandangan Islam dinyatakan bahwa apabila lebih banyak mengkonsumsi barang yang halal maka akan semakin baik. Dapat dilihat pada Gambar 1 peningkatan indifference curve untuk barang halal $\mathrm{X}$ dengan halal Y

Salah satu konsep utama dalam pemasaran modern adalah merencanakan rincian bauran pemasaran. Menurut Sunyoto (2015) ada tujuh bauran pemasaran yang dapat dijadikan acuan setelah perusahaan memutuskan seluruh strategi pemasarannya, yaitu:

1. Produk (Product)

Kombinasi barang dan jasa yang ditawarkan perusahaan kepada pasar sasaran dengan menyediakan keseluruhan konsep obyek, baik itu merupakan barang atau jasa yang 
memberikan sejumlah nilai kepada responden.

2. Harga (Price)

Jumlah uang yang harus dibayarkan pelanggan untuk memperoleh produk atau sejumlah nilai yang ditukarkan pelanggan dengan manfaat penggunaan produk telah didapatkannya.

3. Tempat (Place)

Meliputi kegiatan perusahaan yang membuat produk tersedia bagi pelanggan sasaran.

4. Promosi (Promotion)

Aktivitas yang menyampaikan manfaat produk dan mempengaruhi pelanggan untuk membelinya.

5. Orang (People)

Sumber daya manusia yang menjadi unsur penting, baik dalam produksi maupun penyampaian kebanyakan jasa. Orang-orang secara bertahap menjadi bagian diferensiasi yang mana perusahaan-perusahaan jasa mencoba menciptakan nilai tambahan dan memperoleh keunggulan kompetitif.

6. Proses (Process)

Seluruh prosedur, mekanisme dan kebiasaan dimana sebuah jasa diciptakan dan disampaikan kepada pelanggan, termasuk keputusankeputusan kebijakan tentang beberapa keterlibatan pelanggan dan persoalanpersoalan keleluasaan karyawan. Manajemen proses merupakan aspek kunci penyempurnaan kualitas jasa.

7. Layanan Pelanggan (Customer Service) Konsumen lebih menuntut dan memerlukan tingkat jasa yang lebih tinggi, semakin pentingnya layanan pelanggan (sebagian dikarenakan pesaing memandang jasa sebagai senjata yang kompetitif untuk mendeferensiasikan diri mereka), dan kebutuhan untuk membangun hubungan yang dekat dan lebih langgeng dengan pelanggan.

Preferensi konsumen menunjukkan kesukaan konsumen dari berbagai pilihan produk atau jasa yang ada (Kotler 2006). Teori preferensi dapat digunakan untuk menganalisis tingkat kepuasan bagi konsumen, misalnya bila seseorang ingin mengkonsumsi atau menggunakan sebuah produk atau jasa dengan sumber daya terbatas maka ia harus memilih alternatif pilihan sehingga nilai guna atau utilitas yang diperoleh mencapai optimal. Preferensi konsumen dapat diketahui dengan mengukur tingkat kegunaan dan nilai relatif penting setiap atribut yang terdapat pada suatu produk atau jasa. Atribut yang ditampilkan pada suatu produk atau jasa dapat menimbulkan daya tarik pertama yang dapat mempengaruhi konsumen. Penilaian terhadap produk dan jasa menggambarkan sikap konsumen terhadap produk atau jasa tersebut, sekaligus dapat mencerminkan perilaku konsumen dalam menggunakan atau mengkonsumsi suatu produk atau jasa.

\section{Metode Penelitian}

Jenis data yang digunakan dalam penelitian ini adalah data primer. Data primer diperoleh melalui pengisian kuesioner dan hasil wawancara kepada responden Hotel Sofyan dan responden hotel di Kecamatan Bogor Tengah. Data sekunder digunakan untuk mendukung berbagai teori yang dibutuhkan dalam penelitian ini. Data sekunder diperoleh dari Profil Hotel Sofyan Bogor, Badan Pusat Statistik (BPS), buku, jurnal, skripsi, tesis,serta literatur yang dibutuhkan untuk menunjang pembuatan skripsi.

Penelitian ini dilaksanakan di Hotel Sofyan Inn Srigunting Jalan Pangrango No. 19, Bogor Jawa Barat. Pemilihan lokasi 
penelitian dilakukan secara sengaja (purposive) dengan pertimbangan Hotel Sofyan merupakan hotel syariah pertama di Indonesia, yang mendapatkan penghargaan hotel terbaik pada tahun 2015 dengan penerapan prinsip syariah. Penelitian juga dilakukan pada konsumen hotel konvensional (Hotel Pangrango) yang berada di Kecamatan Bogor Tengah. Pertimbangan pemilihan di Kecamatan Bogor Tengah karena memiliki jumlah hotel paling banyak daripada daerah Kecamatan Bogor lainnya dan memiliki obyek wisata paling banyak. Penelitian ini dilakukan selama bulan Maret 2016.

\section{Teknik Pengumpulan Data}

Data yang dikumpulkan dalam penelitian ini merupakan data primer yang dikumpulkan melalui kuesioner dan wawancara kepada responden hotel syariah dan responden yang tidak memilih hotel syariah. Pengambilan sampel dalam penelitian ini menggunakan teknik penarikan sampel tanpa peluang (Non Probability Sampling) dengan pengambilan datanya menggunakan teknik Purposive Sampling, yaitu prosedur yang biasa dilakukan oleh peneliti dalam memilih contoh berdasarkan pertimbangan tentang beberapa karakteristik yang cocok berkaitan dengan responden yang diperlukan untuk menjawab penelitian (Juanda 2009). Pertimbangan menggunakan teknik ini karena keluar masuknya tamu hotel tidak tetap dan sulit diketahui. Sampel yang diambil dalam penelitian ini sebanyak 59 responden, yang terdiri dari 30 responden yang menginap di Hotel Sofyan dan 29 responden yang menginap di hotel konvensional sekitar Kecamatan Bogor Tengah. Penentuan jumlah responden ini sejalan oleh Gay et a l(2006) yang menyatakan bahwa untuk studi korelasi, setidaknya dibutuhkan 30 responden yang diperlukan untuk menetapkan ada atau tidaknya suatu hubungan.

Metode analisis data yang digunakan dalam penelitian ini adalah menggunakan dua pendekatan, yaitu pendekatan analisis kuantitatif dan pendekatan analisis kualitatif. Pendekatan analisis kuantitatif digunakan untuk menampilkan data dalam bentuk tabel, sedangkan pendekatan analisis kualitatif digunakan untuk menggambarkan karakteristik konsumen dalam memilih hotel syariah. Regresi logistik digunakan untuk menganalisis faktor-faktor yang mempengaruhi preferensi konsumen terhadap hotel syariah. Metode pengolahan data dilakukan dengan menggunakan Microsoft Excel dan SPSS versi 16.

\section{a. Analisis Regresi Logistik}

Regresi logistik atau LOGIT merupakan bagian dari analisis regresi. Analisis ini mengkaji hubungan pengaruh peubahpeubah penjelas $(\mathrm{X})$ terhadap peubah respon (Y) melalui model persamaan matematis tertentu. Secara umum, peubah penjelasnya dapat berupa peubah kategorik maupun peubah numerik, untuk menduga besarnya peluang kejadian tertentu dari kategori peubah respon. Analisis regresi logistik ini merupakan suatu teknik untuk menerangkan peluang kejadian tertentu dari kategori peubah respon (Firdaus et al 2011).

Model logit diturunkan berdasarkan fungsi peluang logistik kumulatif yang dispesifikasikan (Juanda 2009). Model regresi yang digunakan dalam penelitian ini disusun dalam persamaan berikut:

$P i=F(Z i)=F(\alpha+\beta X i)=\frac{1}{1+e^{-}(\alpha+\beta X i)} \ldots . .$.

Keterangan: 
Pi : Keputusan konsumen memilih hotel

D.1: jika memilih hotel syariah

D.0: jika tidak memilih hotel syariah

$\alpha \quad:$ Intersep

$\beta \quad$ : Parameter peubah Xi

$X_{1} \quad$ : Pengetahuan (skor)

$X_{2} \quad$ : Citra hotel (skor)

$X_{3} \quad$ :Layanan Pelanggan/Customer

Service (skor)

$X_{4} \quad$ : Orang/SDM/People (skor)

$X_{5} \quad$ : Tempat/Lokasi/Place (skor)

$X_{6} \quad$ : Proses/Process (skor)

$X_{7} \quad$ : Produk/Product (skor)

$X_{8} \quad$ : Harga/Price (skor)

$X_{9} \quad$ : Promosi/Promotion (skor)

$X_{10} \quad$ : Fasilitas (skor)

$X_{11} \quad$ : Aksesibilitas (skor)

$X_{12} \quad$ : Religiusitas (skor)

Odds Ratio digunakan sebagai peluang terjadinya pilihan 1 (memilih hotel syariah) terhadap peluang terjadinya pilihan 0 (tidak memilih hotel syariah). Nilai odds menjadi suatu indikator kecenderungan konsumen untuk memilih pilihan 1 (hotel syariah). Nilai odds yang semakin besar menunjukkan peluang konsumen untuk memilih hotel syariah semakin besar. Hubungan antara parameter dan odds ratio yaitu:

Odds Ratio $=\frac{P i}{1-P i}$

Keterangan:

$\mathrm{Pi}=$ Rasio peluang terjadi pilihan 1

\section{HASIL DAN PEMBAHASAN}

Karakteristik Responden dan FaktorFaktor yang Mempengaruhi Preferensi Konsumen terhadap Hotel Syariah

Karakteristik responden dalam penelitian ini merupakan konsumen hotel syariah tanpa mengetahui berapa kali sudah pernah menginap di hotel dan kosumen yang tidak memilih hotel syariah. Responden terdiri dari 30 konsumen hotel syariah dan 29 konsumen yang tidak memilih hotel syariah. Dalam hal ini, kriteria yang diambil sebagai responden adalah konsumen Hotel Sofyan yang baru pertama kali atau telah menginap lebih dari satu kali yang dianggap mewakili faktor dimensi kualitas pelayanan yang akan diteliti. Konsumen yang tidak memilih hotel syariah diambil di Kecamatan Bogor Tengah, yang menginap di sekitar Hotel Sofyan Inn Srigunting Bogor.

Berdasarkan hasil temuan di lapangan, mayoritas responden yang memilih hotel syariah dan yang tidak memilih hotel syariah adalah berjenis kelamin laki-laki. Berdasarkan demografi jenis kelamin, tidak ada perbedaan jumlah diantara kedua responden tersebut. Ini menunjukkan bahwa responden berjenis kelamin perempuan lebih mengurangi intensitas menginap di hotel seorang diri, karena akan menimbulkan persepsi negatif dari masyarakat.

Rata-rata usia responden yang memilih hotel syariah adalah 30 tahun, lebih rendah dari rata-rata usia responden yang tidak memilih hotel syariah. Hal tersebut mengindikasikan bahwa mayoritas responden merupakan kelompok muda yang lebih memilih hotel syariah karena mereka memiliki kesadaran yang tinggi untuk lebih memilih menginap di hotel syariah. Alasan responden yang lebih muda memilih hotel syariah antara lain lebih aman dan percaya untuk menginap di hotel, serta terjaga dari persepsi negatif masyarakat. Hotel syariah memiliki citra yang lebih baik dibandingkan hotel konvensional di mata masyarakat, maka dari itu responden yang memiliki usia lebih 
muda lebih percaya menginap di hotel syariah.

Sebesar 53\% responden yang memilih hotel syariah berstatus belum menikah. Artinya, bahwa responden yang berstatus belum menikah lebih memilih hotel syariah karena pada hotel syariah terdapat pemisahan kamar dan pemisahan lantai kamar antara tamu menginap laki-laki single dan tamu menginap perempuan single maka dari itu lebih terjaga dari halhal yang negatif seperti zina yang sangat bertentangan dengan ajaran Islam. Hal ini sesuai dengan Al-Quran Surat Al-Isra ayat 32 yaitu "Dan janganlah kamu mendekati zina. Sesungguhnya zina itu adalah suatu perbuatan yang keji. Dan suatu jalan yang buruk".

Ditinjau dari aspek pendidikan, mayoritas responden yang tidak memilih hotel syariah telah menempuh pendidikan hingga sarjana sebanyak 13 orang atau sebesar 45\%. Responden yang memilih hotel syariah telah menempuh pendidikan hingga sarjana sebesar $47 \%$ atau sebanyak 14 orang. Tidak ada responden yang menempuh pendidikan hingga pasca sarjana pada responden yang memilih hotel syariah.

Diketahui sebanyak 2 orang atau sebesar 7\%yang beragama selain Islam menginap pada hotel syariah. Responden tersebut menginap di Hotel Sofyan karena memiliki kerjasama perusahaan dengan Hotel Sofyan yang sudah berlangsung selama dua tahun. Kondisi ini menunjukkan bahwa hotel syariah tidak hanya melayani tamu menginap yang beragama Islam saja, tetapi juga melayani tamu menginap yang bukan beragama Islam. Sesuai dengan Hadist Riwayat Bukhari dan Muslim yaitu:"Barangsiapa beriman kepada Allah dan hari akhir, maka hendaklah ia memuliakan tamu pada saat istimewanya.
Para sahabat bertanya "Wahai Rasulullah SAW, apakah saat istimewa itu?"Beliau bersabda, "Hari dan malam pertamanya. Bertamu itu adalah tiga hari.Kalau lebih dari tiga hari, maka itu adalah sedekah". Dapat dimengerti dalam hadist tersebut bahwa tamu yang dimaksud mencakup tamu Mukmin maupun kafir. Semua tamu wajib disambut dan dimuliakan berdasarkan ajaran hadist di atas. Seorang muslim juga diperintahkan untuk memenuhi hak-hak tamu, sesuai dengan kemampuan yang dimiliki.

Responden yang tidak memilih hotel syariah mayoritas memiliki jenis pekerjaan terbesar yaitu sebagai wiraswasta, pegawai swasta, dan PNS/BUMN sebanyak masingmasing 8 orang atau sebesar $28 \%$. Jenis pekerjaan terbesar pada responden yang memilih hotel syariah yaitu pegawai swasta dan PNS/BUMN sebanyak masing-masing 9 orang sebesar $30 \%$ dan pekerjaan dengan responden terkecil yaitu ibu rumah tangga sebanyak 1 orang. Hal ini mengindikasikan jumlah ibu rumah tangga tidak sebanyak pekerjaan lainnya karena dalam penelitian ini ibu rumah tangga yang menginap di hotel dikarenakan ikut suami yang sedang dinas.

Terbukti dalam dari hasil penelitian ini rata-rata persepsi bahwa responden yang tidak memilih hotel syariah memiliki tingkat skor religiusitas lebih tinggi dibandingkan dengan responden yang memilih hotel syariah. Responden yang memiliki religiusitas lebih rendah merasa lebih tenang untuk menginap di hotel syariah, karena mereka khawatir dengan rendahnya pengetahuan agama yang mereka miliki maka dari itu mereka lebih percaya untuk memilih hotel syariah yang menjalankan prinsip syariahnya.

Alasan terbesar responden yang telah diwawancara yaitu sebesar $64 \%$ 
mengatakan bahwa memilih hotel syariah karena faktor pelayanan. Alasan terkecil responden memilih hotel syariah adalah lainnya (konsep syar'i) sebesar 3\%.Pelayanan yang diberikan Hotel Sofyan sangat baik. Berdasarkan hasil survei, responden menyatakan bahwa makanan yang dihidangkan untuk menu breakfast ataupun pada menu yang lain memiliki rasa yang baik dan terjamin bersertifikasi halal. Ramahnya karyawan pada Hotel Sofyan seperti mengucapkan salam kepada pengunjng saat pertama kali masuk di front office, sikap dari security Hotel Sofyan yang memberikan rasa aman dan nyaman, dan memberikan layanan yang profesional sesuai dengan standar hotel syariah yang ditetapkan oleh DSN MUI dan Menurut Peraturan Menteri Pariwisata dan Ekonomi Kreatif Republik Indonesia tentang usaha hotel syariah membuat responden lebih memilih untuk menginap di hotel syariah.

Preferensi terhadap Faktor-faktor yang mempengaruhinya.

Faktor-faktor yang diduga mempengaruhi preferensi konsumen terhadap hotel syariah meliputi beberapa variabel independen yaitu pengetahuan, citra hotel, layanan pelanggan, sumberdaya manusia, lokasi, proses, produk, fasilitas, dan religiusitas. Variabel yang akan dilihat terdiri dari dua kemungkinan, yaitu konsumen yang memilih hotel syariah ( $\mathrm{Y}=1$ ) atau konsumen yang tidak memilih hotel syariah ( $\mathrm{Y}=0)$. Pengujian ini menggunakan tingkat kepercayaan 90\% atau dengan taraf nyata $(\alpha)$ sebesar $10 \%$. Model mampu mengklasifikasikan secara keseluruhan responden yang menjadi konsumen hotel syariah maupun hotel konvensional sebesar 83.1\%. Berdasarkan hasil pengolahan dengan regresi logistik dihasilkan nilai overall percentage sebesar $83.1 \%$, artinya klasifikasi $83.1 \%$ baik untuk dibangunnya sebuah model dan variabelvariabel tersebut dapat dijelaskan oleh model.

Nilai R-Square dari model sebesar $69.4 \%$ artinya, dalam penelitian ini sebesar 69.4\% dapat dijelaskan oleh model sisanya dijelaskan di luar model. Selanjutnya, Hosmer and Lemeshow menunjukkan nilai signifikansi model tersebut lebih besar dari taraf nyata $(0.589>0.05)$ artinya, model tersebut telah layak untuk digunakan dalam analisis.

Variabel pengetahuan berpengaruh signifikan terhadap pemilihan hotel pada taraf nyata $10 \%$ dengan odds ratio sebesar 1.456.Artinya, konsumen yang memiliki tingkat pengetahuan satu skor lebih tinggi, berpeluang lebih besar untuk memilih hotel syariah sebesar 1.456 kali, cateris paribus. Hal ini menunjukkan bahwa pertimbangan konsumen untuk memilih hotel syariah dipengaruhi oleh pengetahuan konsumen tentang hotel syariah. Hasil penelitian ini sesuai dengan Mukti (2014) yang menyatakan bahwa variabel pengetahuan berpengaruh positif terhadap preferensi pemilihan tabungan syariah.

Variabel citra hotel berpengaruh signifikan terhadap pemilihan hotel pada taraf nyata 5\% dengan odds ratio sebesar 2.279. Artinya, konsumen yang memiliki tingkat citra hotel satu skor lebih tinggi, berpeluang lebih besar untuk memilih hotel syariah sebesar 2.279 kali, cateris paribus. Variabel ini berpengaruh positif. Hal ini menunjukkan bahwa semakin tinggi citra hotel yang baik maka konsumen akan lebih cenderung memilih hotel syariah. Tingkat citra hotel yang baik dimata konsumen akan berpengaruh pada pertimbangan konsumen untuk memilih hotel syariah. Hal ini sesuai dengan penelitian Susanti (2004) yang menyatakan 
bahwa citra/image hotel turut menentukan sikap konsumen dalam pemilihan hotel. Hotel yang mempunyai citra yang baik dapat memberikan persepsi yang baik pula dimata konsumen.

Variabel layanan pelanggan berpengaruh signifikan terhadap pemilihan hotel pada taraf nyata $10 \%$ dengan odds ratio sebesar 0.549 . Artinya konsumen yang memiliki tingkat pelayanan pelanggan satu skor lebih tinggi, berpeluang lebih besar untuk memilih hotel syariah sebesar 0.549 kali, cateris paribus. Dalam penelitian ini menunjukkan bahwa layanan hotel memiliki hubungan negatif terhadap pemilihan hotel. Penelitian ini menunjukkan bahwa tingginya layanan pada hotel syariah, seperti aturan yang hanya memperbolehkan tamu hotel memiliki status hubungan keluarga atau tidak dan memenuhi persyaratan lain untuk menginap di hotel syariah, maka konsumen semakin tidak memilih untuk menginap di hotel syariah karena terlalu banyak persyaratan pada hotel syariah. Hal ini sejalan dengan penelitian Kartini (2014) yang menyatakan bahwa pelayanan yang diberikan hanyak sedikit bermakna karena hotel syariah masih berusaha mencari jati diri, agar bisa berkembang dengan baik.

Variabel lokasi berpengaruh signifikan terhadap pemilihan hotel pada taraf nyata $5 \%$ dengan odds ratio sebesar 3.412.Artinya, konsumen yang memiliki tingkat lokasi/tempat strategis satu skor lebih tinggi, berpeluang lebih besar untuk memilih hotel syariah sebesar 3.412 kali, cateris paribus. Variabel ini berpengaruh positif. Hal ini menunjukkan bahwa semakin strategis lokasi maka konsumen akan lebih cenderung memilih hotel syariah karena lokasi yang strategis akan berpengaruh pada pertimbangan konsumen untuk memilih hotel syariah.
Hal ini sesuai dengan penelitian Kartini (2014) menyatakan bahwa variabel lokasi berpengaruh positif signifikan terhadap keputusan tamu hotel syariah.

Variabel proses berpengaruh signifikan terhadap pemilihan hotel pada taraf nyata $10 \%$ dengan odds ratio sebesar 1.763 . Artinya, konsumen yang memiliki tingkat proses yang cepat satu skor lebih tinggi, berpeluang lebih besar untuk memilih hotel syariah sebesar 1.763 kali, cateris paribus. Hal ini menunjukkan bahwa semakin cepat suatu proses pemesanan kamar, check in atau check out, proses pembersihan kamar, dan penyajian menu makan pada hotel syariah maka konsumen akan lebih cenderung memilih hotel syariah karena tingkat proses yang cepat akan berpengaruh pada pertimbangan konsumen untuk memilih hotel syariah. Hal ini sesuai dengan penelitian Simanjuntak (2010) yang menyatakan bahwa persepsi tamu hotel terhadap kemudahan pemesanan kamar berpengaruh positif signifikan terhadap keputusan tamu hotel syariah. Hasil penelitian, menunjukkan 49\% konsumen menyatakan pentingnya kemudahan pemesanan kamar.

Variabel fasilitas berpengaruh signifikan terhadap pemilihan hotel pada taraf nyata $10 \%$ dengan odds ratio sebesar 1.530 . Artinya, konsumen yang memiliki tingkat fasilitas satu skor lebih tinggi, berpeluang lebih besar untuk memilih hotel syariah sebesar 1.530 kali, cateris paribus. Variabel ini berpengaruh positif. Hal ini menunjukkan bahwa semakin tinggi fasilitas hotel syariah maka konsumen akan lebih berpeluang memilih hotel syariah karena tingkat fasilitas yang tinggi akan berpengaruh pada pertimbangan konsumen untuk memilih hotel syariah. Hasil ini sesuai dengan penelitian Haris (2015) yang menyatakan bahwa fasilitas 
berpengaruh signifikan terhadap pemilihan bank pada taraf nyata $5 \%$.

Variabel religiusitas berpengaruh signifikan terhadap pemilihan hotel pada taraf nyata $5 \%$ dengan odds ratio sebesar 0.637. Artinya, konsumen yang memiliki tingkat religiusitas satu skor lebih tinggi, berpeluang lebih besar untuk memilih hotel syariah sebesar 0.637 kali, cateris paribus. Variabel religiusitas berpengaruh negatif terhadap pemilihan hotel syariah, yang berarti semakin tinggi tingkat religiusitas responden maka semakin rendah untuk memilih hotel syariah. Karena, konsumen lebih memilih menghindari untuk menginap di hotel.

\section{KESIMPULAN DAN IMPLIKASI}

Berdasarkan hasil penelitian, maka diperoleh kesimpulan sebagai berikut:

a. Karakteristik responden terhadap hotel syariah adalah responden sebagian besar berjenis kelamin laki-laki, usia responden berada pada rentang usia 2052 tahun, sebagian besar responden berstatus belum menikah, sebagian besar responden mayoritas berpendidikan sarjana, sebagian besar responden bekerja sebagai pegawai swasta dan PNS/BUMN, sebagian besar responden beragama Islam.

b. Hasil analisis regresi logistik faktorfaktor yang mempengaruhi preferensi konsumen terhadap hotel syariah menunjukkan ada tujuh variabel yang signifikan mempengaruhi preferensi konsumen tehadap hotel syariah yaitu, pengetahuan, citra hotel, layanan pelanggan, lokasi, proses, fasilitas dan religiusitas. Variabel pengetahuan, citra hotel, lokasi, proses dan fasilitas berpengaruh positif dan variabel layanan pelanggan dan religiusitas berpengaruh negatif. Variabel dengan peluang terbesar yaitu variabel lokasi. Persepsi responden terhadap hotel syariah sudah cukup baik. Atribut yang memiliki nilai rata-rata tertinggi adalah atribut pengetahuan.

\section{DAFTAR PUSTAKA}

[BPS] Badan Pusat Statistik. 2012. Laju Pertumbuhan Kumulatif Produk Domestik Bruto Menurut Lapangan Usaha [Internet]. [diunduh 2015 Oktober]. Tersedia pada:www.bps.go.id [BPS] Badan Pusat Statistik. 2014. Bogor Dalam Angka [Internet]. [diunduh 2015 Oktober]. Tersedia pada:www.bps.go.id [BPS] Badan Pusat Statistik. 2015. Tingkat Penghunian Kamar[Internet]. [diunduh 2016 Januari]. Tersedia pada:www.bps.go.id

[Disbudpar] Dinas Kebudayan dan Pariwisata Kota Bogor.2014. Kecamatan Bogor Tengah Dalam Angka. Bogor (ID): Disbudpar

Firdaus M, Harmini, Afendi FM. 2011. Aplikasi Metode Kuantitatif untuk Manajemen dan Bisnis. Bogor (ID): IPB Press.

Gay LR, Mills GE, Airasian P. 2006. Educational Reasearch Competencies for Analysis and Applications 8th Edition. New Jersey (US): Prentice Hall.

Haris M. 2015. Analisis Faktor-faktor yang Mempengaruhi Preferensi Nasabah Terhadap Bank Syariah di DKI Jakarta [Skripsi]. Bogor (ID): Institut Pertanian Bogor.

Juanda B. 2009. Metodologi Penelitian Ekonomi dan Bisnis. Bogor (ID): IPB Press.

Karim AA. 2012. Ekonomi Mikro Islami. Jakarta (Indonesia): Rajagrafindo Persada.

Kartini WF. 2014. Variabel Yang Mempengaruhi Keputusan Pemilihan Hotel Syariah [Jurnal] EKBISI Volume IX Nomor 1 Tahun 2014. Yogyakarta (ID): Fakultas Syariah dan Hukum UIN Suka Yogyakarta. 
Kotler P. 2006.Prinsip-prinsip Pemasaran. Jakarta (Indonesia): ERLANGGA

Rezeki S, Reza I. 2011.STRATEGI KOMUNIKASI "CHANGE MANAGEMENT" (Studi Kasus: Perubahan Konsep Bisnis dari Hotel Konvensional ke Hotel Syariah).Jurnal Semai Komunikasi Vol. II No. 1.

Sofyan Hotel. 2015. World Halal Travel Award 2015. [Internet]. [diunduh 2015 Oktober 18]. http://sofyanhotel.com

Sunyoto D, Susanti FE. 2015. Manajemen Pemasaran Jasa Merencanakan, Mengelola, dan Membidik Pasar Jasa. Yogyakarta (Indonesia): CAPS (Center for Academic Publishing Service).

Susanti L. 2004. Analisis Tingkat Kepuasan Konsumen Terhadap Kuailitas Pelayanan (Studi Kasus: Hotel Sofyan Betawi Menteng Jakarta) [Skripsi]. Bogor (ID): Institut Pertanian Bogor. 